\title{
Institutional analysis of protection forest area's land use pattern in The North Bandung Area, Bandung Regency
}

\author{
Bagus Budiprakoso ${ }^{\mathrm{a}}$, Iin Ichwandi ${ }^{\mathrm{b}}, \mathrm{Omo} \mathrm{Rusdiana}^{\mathrm{c}}$ \\ a Study Program of Natural Resources and Environmental Management, Graduate School, IPB University, Baranangsiang Campus \\ IPB Bogor, 16144, Indonesia [+62 81298905499] \\ ${ }^{\mathrm{b}}$ Department of Forest Management, Faculty of Forestry, IPB University, Dramaga Bogor, 16680, Indonesia [+62 81287639777] \\ ${ }^{\mathrm{c}}$ Department of Silvikultur, Faculty of Forestry, IPB University, Dramaga Bogor, 16680, Indonesia [+62 8129303348]
}

\section{Article Info:}

Received: 28 - 08 - 2021

Accepted: $01-10-2021$

Keywords:

Commodity and profession transfer, institutional analysis and development(IAD) framework, land use, North

Bandung Area

Corresponding Author: Bagus Budiprakoso Program Studi Pengelolaan Sumber Daya Alam dan Lingkungan, Sekolah

Pascasarjana, Institut Pertanian Bogor;

Tel. +6281298905499

Email:

bagoes_2021@yahoo.co.id

\begin{abstract}
Land use degradation has always been a problem for forest areas. Numerous past studies have investigated that there are patterns in the forest area's land use management that support forest sustainability and society's economy. This research aims to identify the action arena and patterns of interaction, to describe the outcomes of the two land use patterns, and to formulate the strategy related to forest area's land use pattern in North Bandung Area, Bandung Regency. This research used Institutional analysis and development (IAD) framework as the research method. The identified action arena includes the pattern of commodity and profession transfer. The actors involved were State-owned Forest Enterprises (Perum Perhutani), Village Administrations, forest extensions, Forest Village Community Association (FVCA), and Forest and Farm Producers Organization (FFPO). The most dominating actor in land use activities in both patterns was Perum Perhutani, along with FVCA and FFPO. The pattern of interaction that exists between actors was considered appropriate with only minor problems found within its coordination system. The outcome of the application of these two patterns, among others, is to raise public awareness in conserving forests and improving the community's economy. The land management strategy for forest areas can be directed using the Penta helix concept.
\end{abstract}

How to cite (CSE Style $8^{\text {th }}$ Edition):

Budiprakoso B, Ichwandi I, Rusdiana O. 2021. Institutional analysis of protection forest area's land use pattern in The North Bandung Area, Bandung Regency. JPSL 11(3): 463-473. http://dx.doi.org/10.29244/jpsl.11.3.463-473.

\section{INTRODUCTION}

The continuously increasing watershed degradation in Indonesia is predominantly caused by the growth rate of population and changes in land use. Pawitan (2004) explained that land use changes in various cases would almost certainly follow a pattern of conversion from forest use to agriculture, plantations, and then to settlements which are particularly in line with urban developments. Degradation was also reported in the Upper Citarum Watershed. Bandung Regency is a vital administrative area located within the Upper Citarum Watershed area. The North Bandung Area (NBA) is a provincial strategic area that is partly located in Bandung Regency. Land degradation in NBA could also be found in protection forest areas. The entire protection forest area in NBA is classified as degraded land, which subsequently categorized into moderately degraded (64.71\%), degraded (19.05\%), and severely degraded (16.23\%). 
The land use in protection forest areas in NBA does not solely be composed of forests. The condition of land use change in the protection forest areas showed the land use changes from non vegetation land use to vegetation land use. The increase in plantation forest reached up to 90.42 ha from 2009 to 2018. But apart from that, there is also a 206.94 ha of evolving intensive agricultural land over the area. The pattern of land use in the protection forest area in NBA consists of 2 patterns, namely commodity transfer and profession transfer. Commodity transfer is the change of a previous commodity to the new one and it effects to the land use (Irawan, 2005). Profession transfer in this case is the change of a previous profession (farmer) to a profession related to tourism and it has effect to the interest of the farmer and the land use (Umar et al. 2020). Firman (2004) had stated that the dynamics of land use are heavily influenced by government policies in land use legalization. Rustiadi et al. (2011) also underlined that land conversion often arise problems that are interrelated with each other, while are not independent and therefore should be addressed by integrative approaches rather than partial approaches. This study aims to (1) obtain information on the action arena and interaction patterns that occur related to the pattern of commodity and profession transfer over the protection forest area of NBA, (2) describe the impacts (outcomes) that emerged from the interaction of the patterns of commodity and profession transfer within the land use management of the protection forest area of NBA, and (3) formulate strategic directions for the land use management of NBA's protection forest area. The results of this study are expected to be a useful input to the government of the Upper Citarum watershed area, especially NBA, Bandung Regency in their efforts to improve the management of land use of the protection forest area. In addition, this research is intended to be a reliable reference for stakeholders of the Upper Citarum Watershed.

\section{METHODOLOGY}

\section{Location and Time of Study}

This research was conducted in Bandung Regency which is situated within the Upper Citarum watershed area. The sampling process focused on the North Bandung Area (NBA) that is part of the Bandung Regency, with the observed location being protection forest area. The research was conducted from December 2020 to May 2021. The full map of the location of study is presented in Figure 1.

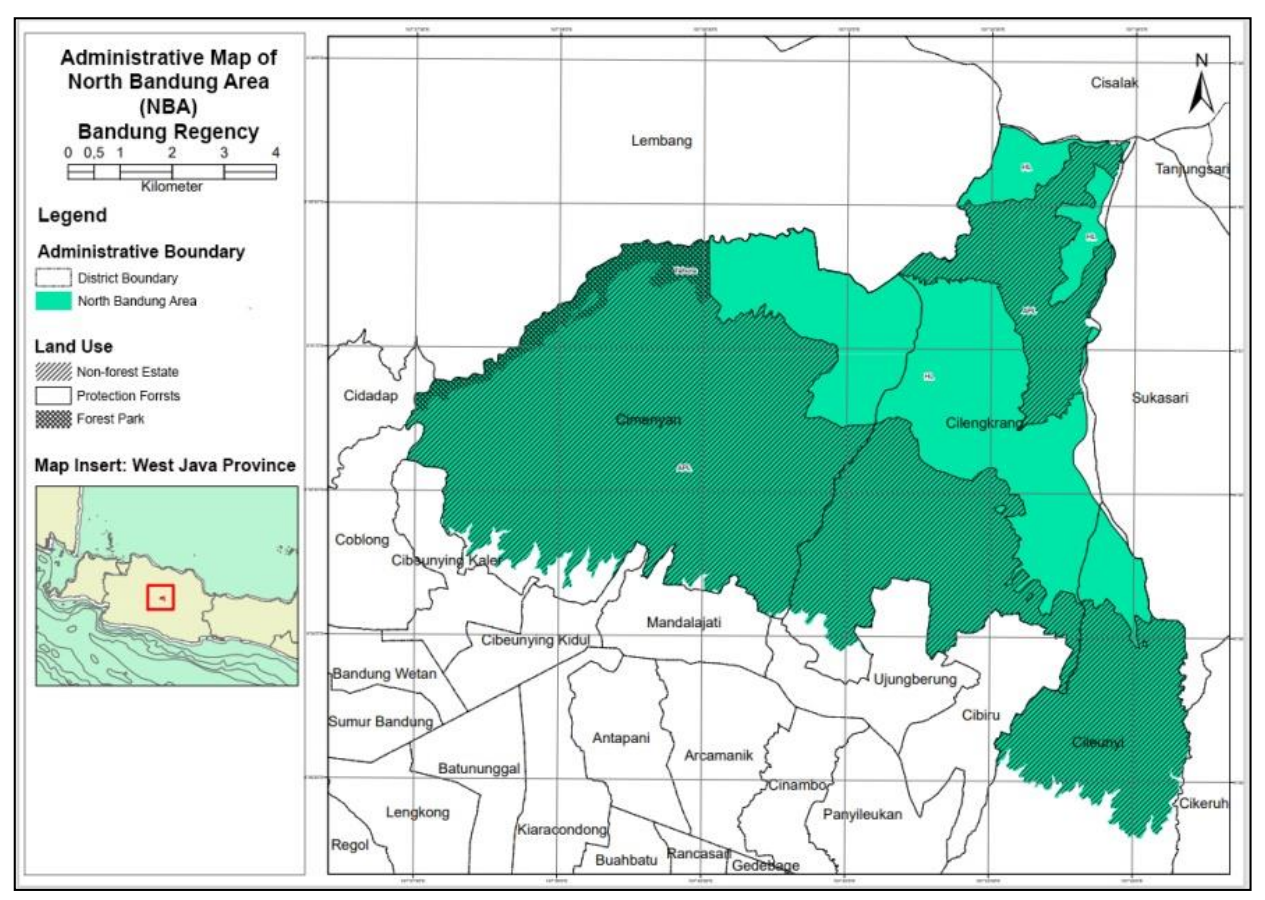

Figure 1 Map of the location of study 


\section{Data Collection Method}

The data collection was done by conducting field surveys and extensive literature studies. The data used were in the form of primary and secondary data sourced from several relevant official agencies. The complete information of the data is presented in Table 1 . The data were processed using a computer equipped with Microsoft Office 2010 and Geographic Information System (GIS) software, ArcGIS 10.1.

Table 1 Data, data sources, employed analysis processes, and outputs of the study

\begin{tabular}{|c|c|c|c|c|c|}
\hline No. & Purpose & Data & Data Source & Data Analysis & $\mathrm{Ou}$ \\
\hline 1. & $\begin{array}{l}\text { To obtain information } \\
\text { regarding the action } \\
\text { arena and the existing } \\
\text { interaction between } \\
\text { the patterns of } \\
\text { commodity and } \\
\text { profession transfer } \\
\text { over the protection } \\
\text { forest area of NBA, } \\
\text { Bandung Regency. }\end{array}$ & $\begin{array}{l}\text { - Land Cover Map of } \\
\text { the Protection Forest } \\
\text { Area Year 1990- } \\
2018 \\
\text { - Data and Map of } \\
\text { Degraded Land } \\
\text { within the } \\
\text { Protection Forest } \\
\text { Area } \\
\text { - Area Map year 2018 } \\
\text { - Demographic Data } \\
\text { of Giri Mekar and } \\
\text { Cimenyan Villages } \\
\text { - Information on the } \\
\text { existing Local } \\
\text { Wisdom in Giri } \\
\text { Mekar and } \\
\text { Cimenyan Villages } \\
\text { The Rules and } \\
\text { Regulations of the } \\
\text { Joint Community } \\
\text { Forest Management } \\
\text { (PHBM) } \\
\text { Questionnaire/ } \\
\text { Interview data }\end{array}$ & $\begin{array}{l}\text { - Directorate } \\
\text { General of } \\
\text { Forestry and } \\
\text { Environmental } \\
\text { Planning, } \\
\text { MoEF (2019) } \\
\text { - Statistics } \\
\text { Indonesia } \\
\text { (2019) } \\
\text { - Protection } \\
\text { Forest and } \\
\text { Watershed } \\
\text { Management } \\
\text { Center } \\
\text { Citarum- } \\
\text { Ciliwung } \\
\text { (2019) } \\
\text { Interview of } \\
\text { relevant } \\
\text { stakeholders/ } \\
\text { official } \\
\text { agencies }\end{array}$ & $\begin{array}{l}\text { - Descriptive } \\
\text { analysis of } \\
\text { biophysical } \\
\text { characteristics } \\
\text { - Community } \\
\text { Attribute } \\
\text { Analysis } \\
\text { - Rules and } \\
\text { regulations } \\
\text { analysis } \\
\text { - Stakeholders } \\
\text { and actors } \\
\text { analysis } \\
\text { (Action } \\
\text { Arena) } \\
\text { - Analysis of } \\
\text { Collective, } \\
\text { dan } \\
\text { Coordination } \\
\text { Action } \\
\text { (interaction } \\
\text { pattern) }\end{array}$ & $\begin{array}{l}\text { Actors and } \\
\text { Situations } \\
\text { (Action Arena) } \\
\text { and Interaction } \\
\text { Patterns of } \\
\text { commodity and } \\
\text { profession tansfer } \\
\text { in the protection } \\
\text { forest area of } \\
\text { NBA, Bandung } \\
\text { Regency. }\end{array}$ \\
\hline 2. & $\begin{array}{l}\text { To describe the } \\
\text { impacts (outcomes) } \\
\text { that emerged from the } \\
\text { interaction of the } \\
\text { patterns of commodity } \\
\text { and profession transfer } \\
\text { within the land use } \\
\text { management of the } \\
\text { protection forest area } \\
\text { of NBA. }\end{array}$ & $\begin{array}{l}\text { Actors and Situations } \\
\text { (Action Arena) and } \\
\text { Interaction Patterns of } \\
\text { commodity and } \\
\text { profession transfer in } \\
\text { protection forest area of } \\
\text { NBA. }\end{array}$ & Output 1 & Anal & $\begin{array}{l}\text { Outcomes of the } \\
\text { action situations } \\
\text { related to the } \\
\text { pattern of } \\
\text { commodity and } \\
\text { profession } \\
\text { transfer in the } \\
\text { protection forest } \\
\text { area of NBA. }\end{array}$ \\
\hline 3. & $\begin{array}{l}\text { Formulate strategic } \\
\text { directions for the land } \\
\text { use management of } \\
\text { protection forest area } \\
\text { of NBA, Bandung } \\
\text { Regency. }\end{array}$ & $\begin{array}{l}\text { Outcomes of the action } \\
\text { situations related to the } \\
\text { pattern of commodity } \\
\text { and profession transfer } \\
\text { over the protection } \\
\text { forest area of NBA. }\end{array}$ & $\begin{array}{ll}\text { - } & \text { Output } 2 \\
\text { - } & \text { Interview of } \\
& \text { relevant } \\
\text { stakeholders/ } \\
\text { official } \\
\text { agencies }\end{array}$ & $\begin{array}{l}\text { Analysis: Penta } \\
\text { helix concept }\end{array}$ & $\begin{array}{l}\text { Strategic } \\
\text { directions for the } \\
\text { land use } \\
\text { management of } \\
\text { protection forest } \\
\text { area of NBA. }\end{array}$ \\
\hline
\end{tabular}




\section{Data Analysis Method}

On the whole, the data analysis procedure in this study consists of several stages. All the data, data sources, employed analysis processes, and outputs of this study are elaborated in Table 1. This research adopts the way of thinking and analytical approach of the Institutional Analysis and Development (IAD) framework. Sabatier et al. (2005) stated that the IAD framework is an integrated approach that aims to explain patterns of interaction and the resulting decisions and behaviors of participants (individuals and/or organizations) within a set of institutional constraints. The most important concepts in the IAD framework are action arena, situations, actors in action, exogenous factors, patterns of interaction and outcomes (Ostrom, 2005).

The action arena is analyzed by using stakeholders and actor analysis. This method uses exogenus factors, which are descriptive analysis of biophysical characteristics, community attribute analysis, and rules/regulation analysis. The stakeholders and actor analysis describe the exogenous factors that has the main effect to land use management. This stakeholders method will identify the key players, context setter, subject, and crowd in land use management in protection forest areas in NBA (Reed et al., 2009). Actor analysis method will analyze what the actors conduct in land use management in protection forest area in NBA. Analysis of collective and coordinated action will describe the pattern of interaction among the actors in land use management in protection forest areas in NBA (Hogl, 2002). The IAD framework can act as a policy diagnostic tool and help to design strategies related to land use management of protection forests in the Upper Citarum watershed, especially in the NBA. The result of the IAD framework is an outcome, which is action arena and pattern of interaction related to land use management in protection forest area in NBA. The result will be the basis to formulate strategic directions for the land use management of protection forest area of NBA, Bandung Regency. The formulating uses pentahelix concept that involve the government, community, industries, academic, and media. This concept will arrange what those stakeholders conduct due to land use management of protection forest area of NBA, Bandung Regency base on the outcomes of IAD framework result.

\section{RESULTS AND DISCUSSIONS}

The land use pattern in the protection forest area in NBA, Bandung Regency consists of 2 patterns, namely commodity and profession transfer. The commodity transfer pattern was observed in Giri Mekar Village of Cilengkrang District. Meanwhile, the pattern of profession shifting was observed in Cimenyan Village of Cimenyan District. These two patterns were implemented in the protection forest area in their respective area under the supervision of the State-owned Forest Enterprise (Perum Perhutani). The institutions of the two land use patterns were analyzed by following the IAD framework, in the terms of exogenous variables, action arena, interaction patterns, and their impact on land use management of the protection forest area of NBA, Bandung Regency.

\section{Exogenous Variables}

Exogenous variables consist of three aspects, namely biophysical characteristics, community attributes, and rules in use. These variables simultaneously shape the action situation and influence each actor's decision-making (Hess and Ostrom, 2007). Exogenous variables of biophysical characteristics that were observed in this study were physical characteristics that affect the land use management of protection forest area in the NBA, which are included in the pattern of commodity and profession transfer.

As for the implementation of commodity transfer patterns, biophysical characteristics consist of data and location conditions. The commodity transfer pattern was implemented in Giri Mekar Village of Cilengkrang District. The village has an area of 206.29 ha. The Forest Management Unit (KPH) that is intersecting with this village is the North Bandung KPH with the West Manglayang Forest Management subUnit (BKPH) and the Mekarmanik Forest Management Resort (RPH). The total area of the protection forest 466 
that can be utilized is 194.60 ha, with 88.95 ha of them already being cultivated. The number of trees being cultivated in the area is 91013 trees with the type of Arabica coffee.

The community attributes identified in the commodity transfer land use pattern were demography, local wisdom, and several actor groups based on their position and interests. Demographic data consists of the number of residents, family head (KK), the broader neighborhood unit (RW), and the smaller neighborhood unit (RT). The total population in Giri Mekar Village was 12 465, which belong to 3502 families. The number of RT and RW was 76 and 21, respectively. The village population density was calculated to be around 61 people/ha. According to SNI 03-1733-2004, this population density could be categorized as low, meaning that the village demographics hardly had any significant land use management problems. Local wisdom that has been carried out in the land use management of the protection forest in Giri Mekar Village is called Ngebon Kopi, which basically is simultaneous cultivation of coffee with other plant species. The top layer is Pinus sp., the middle layer is coffee, and the bottom layer is spices and herbs, such as lemongrass, cloves, and ginger. This Coffee Ngebon activity allows the farmers to harvest as many as three times a year with different commodities in each harvest. Based on their positions and interests, the identified actors were grouped as regional stakeholders, facilitators, field actors, and other supporters. The regional stakeholders were state-owned forest enterprise (Perum Perhutani) and village administration, the facilitators were forestry extension officers from the West Java Forestry Service, the field actors were the Forest Village Community Association (FVCA) and Forest and the Farm Producers Organization (FFPO) Giri Senang, and lastly, other supporters were the central and regional government and investors.

The next exogenous variable in the pattern of commodity transfer is regulation. The regulations that apply to this policy (commodity transfer) are the Decree of the Supervisory Board of State-owned Forest Enterprise Number: 136/KPTS/DIR/2001 concerning the Management of Forest Resources with the Community and the Cooperation Agreement on Forest Utilization on Protection Forests and Coffee Cultivation Business between Perum Perhutani, North Bandung Forest Management Unit (KPH) with FVCA Giri Senang. Broadly, these two regulations regulate the rights and obligations of Perum Perhutani and FVCA Giri Senang in managing the protection forest area in Giri Mekar Village. There are also some set of rules for monitoring activity, evaluation, and penalties in these regulations. Based on the observation and indepth interviews, it was found that the monitoring and evaluation of business and cultivation of coffee in the protection forests were not carried out by Perhutani and penalties for violators related to business and cultivation of coffee in the protection forests were also not conducted with conformity to the formal rules inuse.

Exogenous variables for the pattern of profession transfer consist of biophysical characteristics, community attributes, and rules in-use. The biophysical characteristics of the profession transfer pattern consist of the location for the implementation of the pattern, which is Cimenyan Village of the Cimenyan District, with an area of about 932.17 ha. The FFPO and FVCA involved in the profession transfer were FFPO and FVCA Bongkor. There is also a sort of tourism potential in Cimenyan Village, namely the Puncak Bintang, where visitors can enjoy the beautiful sceneries during the day and the views of city lights at night. The Puncak Bintang is located at an altitude of 1442 masl, making the air temperature cold and therefore suitable for tourism.

The total population in Cimenyan Village is 13 134, belong to 4224 families spread in 23 RW and 83 RT. The population density in Cimenyan Village is around 15 people/ha, which was also categorized as low. The population density in Cimenyan Village implies the inexistence of overpopulation issues and is therefore feasible to accommodate tourism activities. This makes the tourism potential of Puncak Bintang deserve to be developed. Local wisdom found in the pattern of profession transfer is Serah-Serah Daerah and MPTS (Multi-Purpose Three Species) planting with coffee, jackfruit, avocado, cloves, and oranges as the commodity. Serah-Serah Daerah puts forward the concept of activities related to tourism, while planting is carried out by RT, RW, civilian neighborhood guards, and community leaders and does not allow the involvement of external investors. The investors who were given permission were local investors from the 
village community. The actor groups, according to their positions and interests in the pattern of profession transfer were regional stakeholders (Perum Perhutani and village administration), field actors (FVCA and FFPO Bongkor), and other supporters (the central government, regional governments, and local investors).

The regulation that underlies the profession transfer pattern is the same as the one for the commodity transfer pattern, namely the Decree of the Supervisory Board of State-owned Forest Enterprise Number: 136/KPTS/DIR/2001 concerning Management of Forest Resources with the Community. This regulation was prospering in its implementation in the field. Perum Perhutani fully supports the pattern of cooperation in developing the Puncak Bintang tourism and planting perennial trees. The interaction between Perum Perhutani, village administration, FVCA, and FFPO Bongkor was in one direction and in rhythm. In addition, also spotted in its implementation was a profit-sharing scheme being involved.

\section{Action Arena and Interaction Pattern}

The action arena has two main aspects in land use management, namely actors and action situations. The action arena in this study was analyzed using stakeholder analysis and actor analysis. Actors and action situations in the protection forest's land use management were heavily influenced by exogenous factors that had been elaborated on earlier. According to the exogenous factors, especially community attributes and analysis of regulatory content, we were able to identify the actors/stakeholders in NBA. The action arena in this study was analyzed by using stakeholder analysis and actor analysis. Stakeholder analysis related to land management in NBA is revealed in Figure 2. Perum Perhutani, FVCA, and FFPO in both commodity and professional transfer patterns are considered as key players, as they have a great influence and a broad interest in terms of protection forest area land use management in NBA, Bandung Regency.

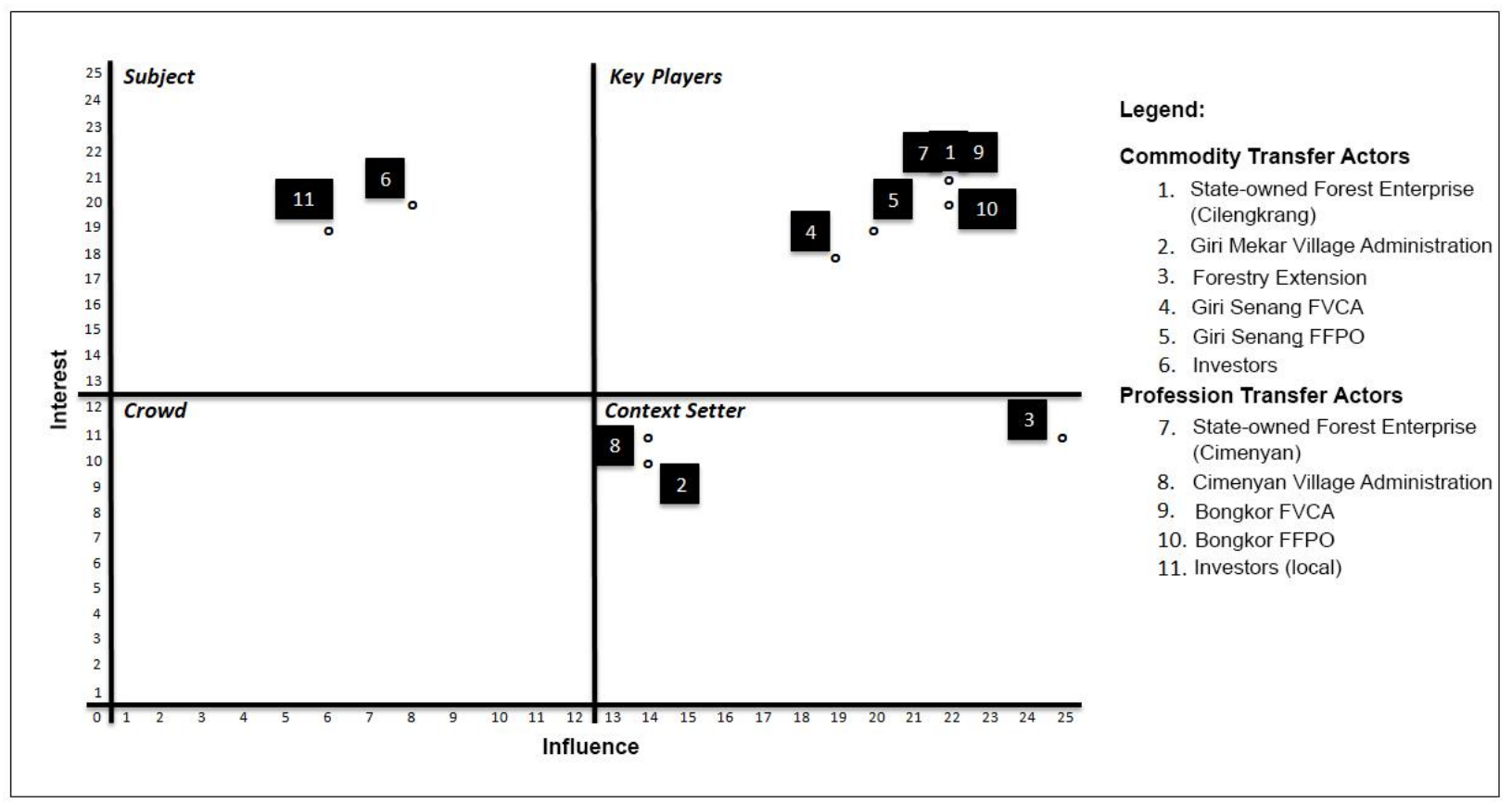

Figure 2 NBA stakeholder matrixes

Actor Analysis identified the actor's actions and categorized them as coercive action, (dis)-incentives, and dominant information. Several identified actors hold actions in the form of official programs that support the land use management of the protection forest area of NBA. The detailed analysis results of actors and their actions can be seen in Table 2. 
Table 2 Analysis score of actors and their actions in NBA, Bandung Regency

\begin{tabular}{|c|c|c|c|c|c|}
\hline No. & Actor & Score & Coercion & (Dis)-Incentive & Dominant Information \\
\hline 1. & $\begin{array}{l}\text { State-owned } \\
\text { Forest } \\
\text { Enterprise } \\
\text { (Cilengkrang) }\end{array}$ & 13 & $\begin{array}{l}\text { Regulations/policies on } \\
\text { land use management in } \\
\text { protection forest area (3) }\end{array}$ & $\begin{array}{l}\text { The existence of penalties } \\
\text { and violations related to } \\
\text { business and commodity } \\
\text { cultivation that does not } \\
\text { comply with the } \\
\text { rules/regulations (5) }\end{array}$ & $\begin{array}{l}\text { Counseling and } \\
\text { supervision from } \\
\text { Perhutani Assistant (5) }\end{array}$ \\
\hline 2. & $\begin{array}{l}\text { Giri Mekar } \\
\text { Village } \\
\text { Administration }\end{array}$ & 9 & $\begin{array}{l}\text { Monitoring of coffee } \\
\text { cultivation, Forest } \\
\text { Landscape Restoration } \\
\text { (FLR), and landscape } \\
\text { conservation activities } \\
\text { (4) }\end{array}$ & N/A (1) & $\begin{array}{l}\text { Socialization and } \\
\text { supervision to the } \\
\text { community through } \\
\text { discussion forums (4) }\end{array}$ \\
\hline 3. & $\begin{array}{l}\text { Forestry } \\
\text { Extensions }\end{array}$ & 10 & $\begin{array}{l}\text { Community assistance in } \\
\text { coffee cultivation (4) }\end{array}$ & N/A (1) & $\begin{array}{l}\text { Socialization and } \\
\text { supervision to the } \\
\text { community (5) }\end{array}$ \\
\hline 4. & $\begin{array}{l}\text { Giri Senang } \\
\text { FVCA }\end{array}$ & 13 & $\begin{array}{l}\text { Cultivation of coffee and } \\
\text { other crops (FLR) (5) }\end{array}$ & $\begin{array}{l}\text { The enforcement of } \\
\text { penalties if the rules is } \\
\text { fail to be fulfilled ( } 4 \text { ) }\end{array}$ & $\begin{array}{l}\text { Education and } \\
\text { socialization to FFPO (4) }\end{array}$ \\
\hline 5. & $\begin{array}{l}\text { FFPO Giri } \\
\text { Senang }\end{array}$ & 12 & $\begin{array}{l}\text { Cultivation of coffee and } \\
\text { other crops (FLR) (5) }\end{array}$ & $\begin{array}{l}\text { The enforcement of } \\
\text { penalties if the rules is } \\
\text { fail to be fulfilled ( } 3 \text { ) }\end{array}$ & $\begin{array}{l}\text { Education and } \\
\text { socialization to the } \\
\text { community(4) }\end{array}$ \\
\hline 6. & Investors & 6 & Cooperation policy (2) & $\begin{array}{l}\text { The provision of a } \\
\text { disincentive if the } \\
\text { cooperation policy is } \\
\text { violated (2) }\end{array}$ & $\begin{array}{l}\text { Community discussion } \\
\text { forum (2) }\end{array}$ \\
\hline 7. & $\begin{array}{l}\text { State-owned } \\
\text { Forest } \\
\text { Enterprise } \\
\text { (Cimenyan) }\end{array}$ & 13 & $\begin{array}{l}\text { Regulations/policies on } \\
\text { land use management in } \\
\text { protection forest area ( } 3 \text { ) }\end{array}$ & $\begin{array}{l}\text { The existence of penalty } \\
\text { and violations related to } \\
\text { business and commodity } \\
\text { cultivation that does not } \\
\text { comply with the } \\
\text { rules/regulations (5) }\end{array}$ & $\begin{array}{l}\text { Counseling and } \\
\text { supervision from } \\
\text { Perhutani Assistant (5) }\end{array}$ \\
\hline 8. & $\begin{array}{l}\text { Cimenyan } \\
\text { Village } \\
\text { Administration }\end{array}$ & 8 & $\begin{array}{l}\text { Monitoring of tourism } \\
\text { activities and Multi- } \\
\text { Purpose Tree Species } \\
\text { (MPTS) planting (4) }\end{array}$ & N/A (1) & $\begin{array}{l}\text { Socialization and } \\
\text { supervision to the } \\
\text { community (5) }\end{array}$ \\
\hline 9. & $\begin{array}{l}\text { FVCA } \\
\text { Bongkor }\end{array}$ & 12 & $\begin{array}{l}\text { Tourism activities and } \\
\text { MPTS planting (5) }\end{array}$ & $\begin{array}{l}\text { The enforcement of } \\
\text { penalties if the rules is } \\
\text { fail to be fulfilled ( } 3 \text { ) }\end{array}$ & $\begin{array}{l}\text { Education and } \\
\text { socialization to FFPO (4) }\end{array}$ \\
\hline 10. & $\begin{array}{l}\text { FFPO } \\
\text { Bongkor }\end{array}$ & 13 & $\begin{array}{l}\text { Tourism activities and } \\
\text { MPTS planting (5) }\end{array}$ & $\begin{array}{l}\text { The enforcement of } \\
\text { penalties if the rules is } \\
\text { fail to be fulfilled ( } 3 \text { ) }\end{array}$ & $\begin{array}{l}\text { Education and } \\
\text { socialization to the } \\
\text { community (5) }\end{array}$ \\
\hline 11. & $\begin{array}{l}\text { Investors } \\
\text { (local) }\end{array}$ & 6 & Partnership policy (2) & $\begin{array}{l}\text { The provision of a } \\
\text { disincentive if the } \\
\text { cooperation policy is } \\
\text { violated (2) }\end{array}$ & $\begin{array}{l}\text { Community discussion } \\
\text { forum (1) }\end{array}$ \\
\hline
\end{tabular}

Collective action describes the level of participation of each actor in collective action related to the land use management of the protection forest area of NBA. The identified collective Actions are stated in Table 3. Collective actions carried out by the community cannot be separated from the programs made by the key stakeholders. Village governments and communities tend to follow programs related to land use management 
that have been already made because it makes them feel that they could get benefits out of these programs. Based on the results of the interviews, the benefits obtained were cleaner water resources, one less flood occurrence from time to time thanks to the extensive tree planting program, and lastly, improvement in the community's economy as a result of the inclusive employment for coffee cultivation and tourism production activities.

Table 3 Collective Actions at NBA, Bandung Regency

\begin{tabular}{|c|c|c|c|c|}
\hline No & Actor & Score & $\begin{array}{l}\text { Participation } \\
\text { level in the } \\
\text { Collective } \\
\text { Action }\end{array}$ & Collective Action \\
\hline 1. & $\begin{array}{l}\text { State-owned } \\
\text { Forest } \\
\text { Enterprise } \\
\text { (Cilengkrang) }\end{array}$ & 23 & High & $\begin{array}{l}\text { Provide access to the community for land management in } \\
\text { protection forest areas with agreed rules and cooperation } \\
\text { (coffee cultivation). }\end{array}$ \\
\hline 2. & $\begin{array}{l}\text { Giri Mekar } \\
\text { Village } \\
\text { Administration }\end{array}$ & 15 & Low & $\begin{array}{l}\text { Provide permits and support for coffee cultivation } \\
\text { activities. }\end{array}$ \\
\hline 3. & $\begin{array}{l}\text { Forestry } \\
\text { Extensions }\end{array}$ & 18 & Low & $\begin{array}{l}\text { Provide education in coffee cultivation to commodity } \\
\text { transfer farmers. }\end{array}$ \\
\hline 4. & $\begin{array}{l}\text { Giri Senang } \\
\text { FVCA }\end{array}$ & 24 & High & $\begin{array}{l}\text { Carry out coffee cultivation activities in accordance with } \\
\text { the rules and in collaboration with Perum Perhutani and } \\
\text { the village. }\end{array}$ \\
\hline 5. & $\begin{array}{l}\text { FFPO Giri } \\
\text { Senang }\end{array}$ & 24 & High & $\begin{array}{l}\text { Carry out coffee cultivation from planting to production by } \\
\text { utilizing the protection forest area of Perum Perhutani. }\end{array}$ \\
\hline 6. & Investors & 8 & Low & Provide capital for the coffee beans marketing. \\
\hline 7. & $\begin{array}{l}\text { State-owned } \\
\text { Forest } \\
\text { Enterprise } \\
\text { (Cimenyan) }\end{array}$ & 22 & High & $\begin{array}{l}\text { Provide access to the community for land management in } \\
\text { protection forest areas with agreed rules and cooperation } \\
\text { (Puncak Bintang tourism). }\end{array}$ \\
\hline 8. & $\begin{array}{l}\text { Cimenyan } \\
\text { Village } \\
\text { Administration }\end{array}$ & 18 & Low & $\begin{array}{l}\text { Provide permits and support for tourism activities in } \\
\text { Puncak Bintang. }\end{array}$ \\
\hline 9. & $\begin{array}{l}\text { FVCA } \\
\text { Bongkor }\end{array}$ & 24 & High & $\begin{array}{l}\text { Develop the tourism potential of Puncak Bintang in } \\
\text { accordance with the rules and in cooperation with Perum } \\
\text { Perhutani and villages. }\end{array}$ \\
\hline 10. & FFPO Bongkor & 25 & High & $\begin{array}{l}\text { Develop and market the tourism of Puncak Bintang from } \\
\text { planning to production by utilizing the protection forest } \\
\text { area of Perum Perhutani. }\end{array}$ \\
\hline 11. & $\begin{array}{l}\text { Investors } \\
\text { (local) }\end{array}$ & 9 & Low & $\begin{array}{l}\text { Provide capital for the development of Puncak Bintang } \\
\text { tourism }\end{array}$ \\
\hline
\end{tabular}

The status of coordination, issues, and failure of coordination between government agencies has a unique contribution to the land use management of protection forest area in NBA, Bandung Regency. The results of the analysis based on the coordination capacity scale of Metcalfe (1997) in Hogl (2002) are presented in Table 4. In general, the two patterns of land use management in protection forests were in a good coordination stage (Stages 7 and 8). The status of coordination is at the level of excessive activity, 
meaning that despite the programs having led towards the common goal, but considerations between institutions in decision-making still have to be improved further.

Tabel 4 Status of coordination, issues, and coordination failure in the land use management of protection forest area in NBA, Bandung Regency

\begin{tabular}{|c|c|c|c|c|c|}
\hline No & $\begin{array}{c}\text { Management } \\
\text { Conceptual } \\
\text { Area }\end{array}$ & $\begin{array}{l}\text { Involved } \\
\text { institutions }\end{array}$ & $\begin{array}{c}\text { Coordination } \\
\text { Status }\end{array}$ & Coordination Issues & $\begin{array}{c}\text { Coordination Failure } \\
\text { due to the capacity scale } \\
\text { of Metcalfe (1997) in } \\
\text { Hogl (2002) }\end{array}$ \\
\hline 1. & $\begin{array}{l}\text { Commodity } \\
\text { Transfer }\end{array}$ & $\begin{array}{l}\text { - State-owned } \\
\text { Forest } \\
\text { Enterprise } \\
\text { - Giri Mekar } \\
\text { Village } \\
\text { - Forestry } \\
\text { Extensions } \\
\text { - FVCA Giri } \\
\text { Senang } \\
\text { - FFPO Giri } \\
\text { Senang } \\
\text { - Investors }\end{array}$ & Excessive & $\begin{array}{l}\text { Lack of monitoring and } \\
\text { evaluation from Perum } \\
\text { Perhutani to FVCA and } \\
\text { FFPO Giri Senang. }\end{array}$ & $\begin{array}{l}\text { Stage } 8 \text { : There has been } \\
\text { an ordinance of the } \\
\text { overall strategy of the } \\
\text { relevant sector. }\end{array}$ \\
\hline 2. & $\begin{array}{l}\text { Profession } \\
\text { Transfer }\end{array}$ & $\begin{array}{l}\text { - State-owned } \\
\text { Forest } \\
\text { Enterprise } \\
\text { - Cimenyan } \\
\text { Village } \\
\text { - FVCA } \\
\text { Bongkor } \\
\text { - FFPO } \\
\text { Bongkor } \\
\text { - Investors } \\
\text { (local) }\end{array}$ & Excessive & $\begin{array}{l}\text { Lack of consultation } \\
\text { with forestry } \\
\text { extensions. }\end{array}$ & $\begin{array}{l}\text { Stage } 7 \text { : There are } \\
\text { already ordinance and } \\
\text { mutual agreements and a } \\
\text { number of related sector } \\
\text { development priorities. }\end{array}$ \\
\hline
\end{tabular}

The results of the IAD analysis in the land use management of protection forest area of the NBA, Bandung Regency have led to a positive outcome. The outcome that was emerged from the policies and actions of the commodity and professional transfer patterns related to the land use management in the protection forest area was that the forests remain sustainable with well-maintained vegetation and a better community's economic situation. People are becoming more aware of the importance of preserving the forest as it indirectly helps them to provide a good and healthy environment, as well as prevent catastrophic disaster like floods and landslides. The community's economic situation has also been improved in line with forest sustainability, where job vacancies for coffee cultivation and tourism from upstream to downstream of the production are increasingly offered to the community from time to time. In addition, other identified impacts were the increase in trust and cooperation between communities and institutions related to land use management in NBA's protection forest area. 


\section{Strategic Directions for Land Use Management in the Protection Forest Area}

The strategic directions for land use management in protection forest areas are presented in Table 5 . Stakeholders were divided into 5 groups, namely government, local communities, private sector, academics, and media. In general, the direction of land use management strategies in protection forest area of NBA focuses on government stakeholders and local communities. The government, in this case, is Perum Perhutani is located in Giri Mekar Village of Cilengkrag District and Cimenyan Village of Cimenyan District. Perum Perhutani can process more legal access to communities in managing the protection forests in a systematic and coordinated manner.

Other stakeholders who can also be directed to play an important role in managing the land use over the protection forest area of NBA are local communities, which in this case are FVCA and FFPO. FVCA and FFPO stakeholders hold the potential to develop the pattern of commodity and professional transfer over the protection forest area. Other stakeholders such as the private sector, academics, and also media can be directed as supporters in the development of the patterns of commodity and professional transfer with their respective obligations and expertise.

Table 5 Strategic directions for land use management of protection forest in NBA, Bandung Regency

\begin{tabular}{|c|c|c|}
\hline No. & Stakeholder & Land Use Management Strategy for Protection Forest Area \\
\hline 1. & Government & $\begin{array}{l}\text { - Supporting legal access to land management of protection forest area in } \\
\text { accordance with regulations that prioritize forest conservation and community } \\
\text { economic development, both for commodity and professional transfers patterns. }\end{array}$ \\
\hline 2. & $\begin{array}{l}\text { Local } \\
\text { Community }\end{array}$ & $\begin{array}{l}\text { - Commodity transfer: developing coffee production from planting to marketing } \\
\text { and providing education and socialization related to coffee cultivation in } \\
\text { protection forest area to the surrounding community. Profession transfer: } \\
\text { developing tourism within the protection forest area with forest conservation } \\
\text { being one of the focuses. }\end{array}$ \\
\hline 3. & $\begin{array}{l}\text { Private } \\
\text { party }\end{array}$ & $\begin{array}{l}\text { - Commodity transfer: providing capital support for the development of coffee } \\
\text { production. Profession transfer: providing capital support for the development of } \\
\text { tourist villages (for local investors) }\end{array}$ \\
\hline 4. & Academics & $\begin{array}{l}\text { - Conducting studies related to the management of land use in protection forest } \\
\text { areas following the scientific principles. } \\
\text { - Cooperating with the government in managing land use and assisting the } \\
\text { community in carrying out different activities related to land use management so } \\
\text { that the forests remain sustainable and can be beneficial for the community's } \\
\text { economy. }\end{array}$ \\
\hline 5. & Media & $\begin{array}{l}\text { - Developing instruments for promotion and information distribution for the } \\
\text { community as part of the land use management of the protection forest area. }\end{array}$ \\
\hline
\end{tabular}

\section{CONCLUSIONS}

The action arena in the land use management of the protection forest of North Bandung Area (NBA), Bandung Regency, is composed of 2 patterns, namely the pattern of commodities and profession transfer. The actors involved were the State-owned Forest Enterprise (Perum Perhutani), Village Administration, forestry extensions, as well as Forest Village Community Association (FVCA) and Forest and Farm Producers Organization (FFPO). The most dominant actor in both patterns is Perum Perhutani, along with FVCA and FFPO. Perum Perhutani plays a role in facilitating the legalization of land use for both patterns, while FCVA and FFPO Giri Senang cultivating coffee in the 88.95 ha land, and FVCA and FFPO Bongkor developing Puncak Bintang tourism that is within the protection forest area of the NBA. The pattern of interactions that exists between actors is prospering with only occasional minor problems and coordination 472 
issues that have been addressed properly. The outcome of the implementation of these two patterns, among others, is to raise public awareness in conserving forests and improving the community's economy. The land management strategy for protected forest areas can be directed by using the Penta helix concept.

\section{ACKNOWLEDGEMENT}

The authors would like to thank and appreciate the community of the Upper Citarum watershed, Giri Mekar village of the Cilengkrang district, and Cimenyan of the Cimenyan district, the Head of the CitarumCiliwung Watershed and Protection Forest Management Center, and the center's staff who had been very generous with providing assistance during this research.

\section{REFERENCES}

[Perum Perhutani] Perusahaan Umum Kehutanan Negara Indonesia. 2001. Keputusan Dewan Pengawas Perum Perhutani Nomor: 136/KPTS/DIR/2001 tentang Pengelolaan Sumber Daya Hutan Bersama Masyarakat. Jakarta (ID): Perum Perhutani.

Firman T. 2004. Major issues in indonesia's urban land development. Land Use Policy. 21: 347-355. doi: 10.1016/j.landusepol.2003.04.002.

Hess C, Ostrom E. 2007. Private and common property right. Workshop in Political Theory and Policy Analysis. Indiana, Amerika Serikat. Bloomington (US): Indiana University.

Hogl K. 2002. Inter-Sectoral Co-ordination. Vienna (AT): Institute of Forest Sector Policy and Economics University of Agricultural Sciences.

Irawan B. 2005. Koversi Lahan Sawah Menimbulkan Dampak Negatif Bagi Ketahanan Pangan dan Lingkungan. Bogor (ID): Pusat Analisis Sosial Ekonomi dan Kebijakan Pertanian.

Ostrom E. 2005. Understanding Institutional Diversity. New Jersey (US): Princeton University Press.

Pawitan H. 2004. Perubahan penggunaan lahan dan pengaruhnya terhadap hidrologi daerah aliran sungai. In: Adimihardja A, Agus F, Pawitan H, Husen E, editor. Prosiding Seminar Multifungsi Pertanian dan Konservasi Sumberdaya Lahan; 2004 Jan 07; Bogor, Indonesia. Bogor (ID): Badan Penelitian dan Pengembangan Pertanian. pp 65-80.

Reed MS, Graves A, Dandy N, Posthumus H, Hubacek K, Morris J, Prell C, Quinn CH, Stringer LC. 2009. Who's and why? A typology of stakeholder analysis methids for natural resource management. Journal of Environmental Management. 90: 1933-1949.

Rustiadi E, Saefulhakim S, Panudju DR. 2011. Perencanaan dan Pengembangan Wilayah. Bogor (ID): IPB Pr.

Sabatier PA, Leach W. Lubell M, Pelkey N. 2005. Theoretical frameworks explaining partnership success. In: Sabatier PA, Lubell M, Focht W, editor. Swimming upstream: Collaborative approaches to watershed management. Cambridge (US): MIT Press.

Umar R, Hamzah N, Arifin Z. 2020. Pengaruh pelatihan vokasi dan keputusan alih profesi terhadap minat wirausaha. JMS. 1(1): 93-104. 